\title{
Factors Affecting Women's Knowledge and Behavior About Reproductive Health and Delivery Method Preferences
}

\section{Kadınların Üreme Sağlığı ve Doğum Metodu Tercihleri ile İlişkili Bilgi Düzeylerini ve Davranışlarını Etkileyen Faktörler}

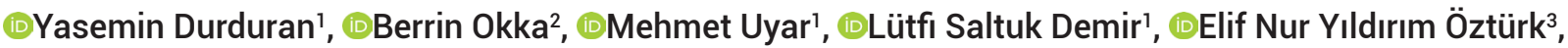 \\ (1)Tahir Kemal Şahin'
}

'Necmettin Erbakan University, Meram Faculty of Medicine, Department of Public Health, Konya, Turkey

${ }^{2}$ Necmettin Erbakan University, Meram Faculty of Medicine, Department of Medical History and Ethics, Konya, Turkey

${ }^{3}$ Konya Akşehir District Health Directorate, Public Health, Konya, Turkey

Copyright (C) 2020 by authors and Medical Records Publishing Inc.

\begin{abstract}
Aim: In this study, it is aimed to determine the delivery method preferences, sexual and reproductive health knowledge and attitude status, and related factors in women treated in primary care centers in Konya city center.

Material and Methods: This study is conducted in 2015 and, as the data gathering tool, a questionnaire prepared by the authors is used. Data are summed up with descriptive statistics and analyzed with appropriate statistical tools. The level of significance is set as $p<0.05$.

Results: This study was conducted with 791 women participants. The mean age of the participants was $35.3 \pm 7.5$ years. The mean age of the first menstruation was $13.3 \pm 1.5$ years. Of the participants, $69.7 \%$ answered the question 'Do you know the methods of family planning?' as 'I know'. Among the method users, the use of condoms was the first choice (38.3\%). Of the participants, $37.1 \%$ indicated that they used a modern family planning method. Among the participants, $32.1 \%$ stated that they had the vaginal smear test and $15.8 \%$ had mammography. The ideal way of giving birth was 'vaginal birth' according to $70.7 \%$ of the participants, providing that there was no risk.

Conclusion: The fact that the percentage of condom use is higher than that of the other family planning methods is promising because it suggests a male participation in family planning. The participants' knowledge of the age for vaginal smear test and mammography screening, and the number of participants practicing them are low. Most of the participants state that the ideal mode of delivery was vaginal delivery; however, only half would prefer it. We believe that it will be helpful to perform regular informative activities on reproductive health and thereby raise awareness regarding the subject.
\end{abstract}

Keywords: Delivery method, reproductive health, sexual health

$\mathrm{Oz}$

Amaç: Bu çalışmada, Konya şehir merkezindeki birinci basamak sağlık kurumlarına başvuran kadınlarda doğum yöntemi tercihlerinin, cinsel sağlık ve üreme sağlığı bilgi ve davranışlarının belirlenmesi amaçlanmıştır.

Materyal Metod: Bu çalışma 2015 yılında yürütülmüş ve veri toplama aracı olarak yazarlar tarafından hazırlanmış bir anket kullanılmıştır. Veriler tanımlayıcı istatistiklerle özetlenmiş ve uygun istatistiksel yöntemler ile analiz edilmiştir. Anlamlılık düzeyi $p$ $<0.05$ olarak belirlenmiştir.

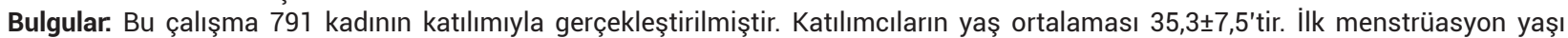
$13,3 \pm 1,5$ 'tir. Yöntem kullanıcıları arasında kondom kullanımı ilk tercihtir (\%38,3). Kadınların \%69,7'si aile planlaması yöntemlerini bildiğini ifade etmiştir. Katılımcıların \%37,1'i modern bir aile planlaması yöntemi kullandıklarını belirtmiştir. Katılımcıların \%32,1'i daha önce vajinal smear ve \%15,8'i mamografı yaptırmıştır. Katılımcıların \%70,7'sine göre doğum yapmanın ideal yolu 'risk olmaması koşuluyla vajinal doğum'dur.

Sonuç: Kondom kullanım oranının diğer aile planlaması yöntemlerinden daha yüksek olması ümit vericidir, çünkü erkeklerin aile planlamasına katılımı söz konusudur. Katılımcıların vajinal smear ve mamografı için doğru yaşları bilme ve bu taramaları yaptırma oranı düşüktür. Katılımcıların çoğu ideal doğum şeklinin vajinal doğum olduğunu belirtmiş olsa da sadece yarısı normal doğum tercih etmiştir. Üreme sağlığı konusunda düzenli olarak bilgilendirici faaliyetler yürütmenin ve böylece konuyla ilgili farkındalığın artırımasının faydalı olacağına inanıyoruz

Anahtar Kelimeler. Doğum metodu, üreme sağlığı, cinsel sağlık 


\section{INTRODUCTION}

Reproductive health deals with the reproductive system, functions, and processes at every stage of life. The World Health Organization defines reproductive health as having a satisfactory and safe sexual life, reproductive abilities, and freedom to decide on using reproductive abilities (1). Sexual and reproductive health (SRH) services include reproductive rights, reproductive health problems, family planning services, prevention of sexually transmitted infections, and safe motherhood (2). Prenatal care, the mode of delivery, healthy delivery and postnatal care are also among safe motherhood issues (3).

Generally, the physiological structure of the female body is suitable for a vaginal birth. However, in some cases, it may be highly risky for the mother or the fetus. In this case, the cesarean method is recommended (4). However, the increase in cesarean delivery rates is striking, which is considered as an emerging public health problem (5). According to the Turkey Demographic and Health Survey (TDHS) 2003, the cesarean birth rate was $21.2 \%$, which increased to $48 \%$ in 2013 TDHS and 52\% in 2018 TDHS (6-8).

Given this increase in the cesarean birth rate, knowing the preferences and thoughts of women on delivery methods, their knowledge of reproductive health, and how they practice it in their lives will be useful in planning sexual and reproductive health (SRH) studies. In our study, after investigating the delivery method preferences, $\mathrm{SRH}$ knowledge and attitude status and related factors in 18-49-years-old women applied in the primary care centers (PCCs) in X city center, it is aimed to determine the lack of knowledge or misinformation related to the topic in the study group and thus to contribute to SRH studies. Secondarily, it is aimed to support the reorganization of the content of the community training to be carried out based on the needs.

\section{MATERIAL AND METHODS}

\section{Type of Study}

This cross-sectional study was conducted in Konya city center between January and April, 2015. Konya is the largest province of Turkey in terms of land area, and the seventh province in terms of population. Konya is an important health center with medical faculties, public and private hospitals, and easily accessible PCCs.

\section{Target Population and Sample Size}

The study included 18-49-years-old women. Considering the fact that the rate of cesarean delivery according to a previous study was found as $44 \%$, the sample size was calculated as 791 with G-Power 3.1.9.2 sample size calculation program, with an effect size of 0.05 , 0.80 power, and 0.95 confidence level $(9,10)$. Assuming that the women living in three districts in the city center have similar lifestyles and considering the 2013 Turkish Statistical Institute (TSI) population data, 379 women from Selçuklu district, 223 women from Meram district, and 189 women from Karatay district were planned to be included in the study after the 18-49-year-old women population of every district were weighted. Then, the data were obtained via a survey randomly administered to the women admitted at PCCs.

\section{Data Collection}

The questionnaire was administered to the women who admitted to the PCCs and who volunteered to participate were interviewed face-to-face after we obtained their consent verbally. The questionnaire included 39 items about the participants' knowledge of family planning and women's cancer screenings, as well as about their obstetric histories.

\section{Permissions}

Before the study, the health directorate was informed and verbal permission was obtained. Then, approval was obtained from the Necmettin Erbakan University Meram Medical Faculty ethics committee (Number: 2014/88).

\section{Statistical Analyze}

After the data normal distribution compatibility analyses, data was summarized as percent and arithmetic mean \pm standard deviation. Chi-square $(\chi 2)$ test was used to compare categorical data and Student's t-test was used in independent groups to compare the numeric data. Variables with significant differences in the chi-square analysis were analyzed by logistic regression. Significance level was set as $p<0.05$.

\section{RESULTS}

\section{Socio-demographic findings}

The mean age of the 791 women participating in the study was $35.3 \pm 7.5$ years. The sociodemografic features are presented in Table 1.

\section{Some Reproductive Health Data}

The mean age of the first menstruation was $13.3 \pm 1.5$ years. Participant women's some reproductive health properties are in Table 2.

\section{Family planning method knowledge/practice}

Of the participants, $69.7 \%$ answered the question 'Do you know the methods of family planning?' as 'I know'. The other family planning method practice is presented in Table 3.

Of the participants, $37.1 \%$ indicated that they used a modern family planning method. Knowing a modern family planning method correctly was higher in the high school/ higher education graduates compared to the others (Table 4).

Married participants are 6.4 times (95\% Cl: $2.31-16.77)$ more likely to use a family planning method (Table 5 ). 
Table 1. Participant women's sociodemografic features

Age

Marital status [n(\%)]

Having children status [n(\%)]

Children number

Husbands' education levels [n(\%)]

Family type $[\mathrm{n}(\%)]$

At least one chronic disease like hypertension, diabetes, iron deficiency anemia, asthma etc. [n(\%)]
Mean $\pm S D$

Married

Divorced/widow

Yes

No

Mean $\pm S D$

Women's education levels [ $\mathrm{n}(\%)]$

Elementary school

Secondary school

High school

University

Not literate

Elementary school

Secondary school

High school

University

Nuclear family

Other (Single, extended family etc)

Yes

No
$35.3 \pm 7.5$

733(92.7)

58(7.3)

765(96.7)

26(3.3)

$2.09 \pm 1.0$

32(4.0)

275(34.8)

96(12.1)

176(22.3)

212(26.8)

12(1.6)

177(23.0)

97(12.6)

195(25.3)

289(37.5)

664(83.9)

$127(16.1)$

170(21.5)

$621(78.5)$

Table 2. Participant women's some reproductive health properties

Age of the first menstruation

Age of the first marriage

Age of the first birth

Number of live delivery

Induced abortion [n(\%)]

Experienced at least one miscarriage $[\mathrm{n}(\%)]$

Having at least one planned pregnancy $[n(\%)]$

Sources of information about family planning methods [n(\%)]
Mean $\pm S D$

$13.3 \pm 1.5$

Mean $\pm S D$

$21.1 \pm 3.7$

Mean $\pm S D$

$22.4 \pm 4.2$

Mean $\pm S D$

$3.0 \pm 4.4$

Yes

$50(6.3)$

No

739(93.7)

Yes

150(19.0)

No

640(81.0)

Yes

$538(68.0)$

No

253(32.0)

209(26.4)

Not receive any information about the subject

$301(38.1)$ (MCHFP)

Hospitals

125(15.8)

Friends/neighbors

95(12.0)

Television/internet 
Table 3. Status of participants' knowledge and use of family planning methods

Family planning method knowledge/attitude variables

Number(\%)

Participants' Belief about Their Knowledge About Family Planning Methods

Believing that they know

$551(69.7)$

Participants who could name a method

463 (58.5)

*Methods known

OCP

$329(41.6)$

IUD

Condom

287 (36.3)

Injectable contraceptives

$79(10.0)$

Tubal ligation

27 (3.4)

Traditional method

Those who cannot name any methods

$240(30.3)$

The ones who do not know
Using the Family Planning Methods

** Current Methods Used

Condom

IUD

107 (31.3)

OCP

$58(17.0)$

Traditional method

Tubal ligation

Injectable contraceptives

Non-method users

To have used the family planning method at any time in her life

* More than one method name has been specified, each method was scaled in for all participants

**Percent distribution of method users

\section{Knowledge of cancer types in women and the practice of screening tests}

Of the participants, $32.1 \%$ had had a vaginal smear before. Among the reasons of smear tests, the most common one was control purposes (15.4\%). Another reason was that smear test was decided by the doctor for symptoms such as irregular bleeding, infection, itching etc. Of the participants, $31.1 \%$ answered yes to the question "Do you know how old women should undergo the vaginal smear test according to the national criteria in Turkey?", of whom, $72.8 \%$ provided the correct age limit $(22.6 \%$ of all participants knew correctly).

Of the participants, $39.7 \%$ answered yes to the question "Do you know, according to the national criteria, how old one should be to have the mammography for breast cancer screening?", Of these 314 participants, $57.9 \%$ knew the age correctly (23.0\% of all participants knew correctly). It was found that $15.8 \%$ of the participants had mammography before, of whom, 6.6\% had it due to control purposes or because of a breast cancer history in the family. The others had it due to breast pain, swelling, mass sensation, inverted nipples, and cancer follow-up. The most common cancer type in women was breast cancer according to $58.4 \%$ of the participants, which was followed by uterine cancer (24.8\%) and lung cancer $(2.1 \%)$, and $14.7 \%$ had no idea about it.

\section{Delivery method and preference}

It was found that the first birth of $60.6 \%$ of the participants was normal delivery, $27.4 \%$ cesarean section; $3.2 \%$ had no child, and $8.8 \%$ did not answer.

Of the participants, $87.1 \%$ answered when they were asked about the person with the greatest influence in determining the delivery method. Among the answers, the most effective person in determining the delivery method was doctors (63.0\%), followed by self (26.3), a friend/ relative/acquaintance $(4.4 \%)$, husband (3.9\%), and mother (2.5\%). Of the participants, $90.9 \%$ answered the question about the reason for preferring normal delivery for at least one birth, of whom, 51.6\% preferred normal delivery because it is healthy, $11.8 \%$ to be discharged from hospital more quickly, $11.4 \%$ to return quickly to their normal life, $8.8 \%$ because they had normal delivery before, and $7.3 \%$ because they discharged from hospital quickly, because it was healthy, and because they returned to normal life quickly. Of the participants whose first delivery was a cesarean section, $45.9 \%$ had cesarean for their subsequent deliveries. Reasons for choosing cesarean delivery in one or more deliveries were easiness and painlessness (9.9\%), difficulty in a previous delivery $(4.4 \%)$, fear of normal delivery $(4.2 \%)$, having had a cesarean delivery before $(1.9 \%)$, because it is safe for the baby $(1.8 \%)$, and a combination of these reasons $(6.7 \%)$. 


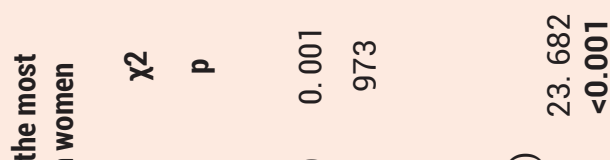

to.

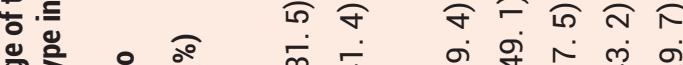

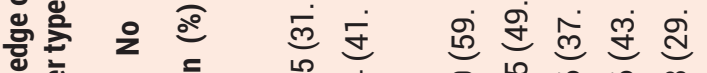

흘

훙

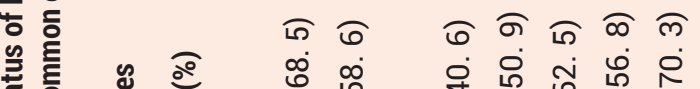

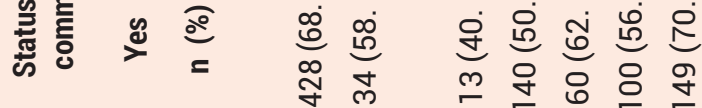

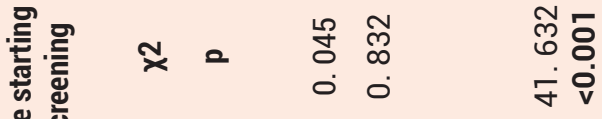

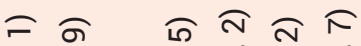

훙

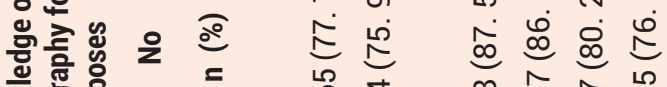

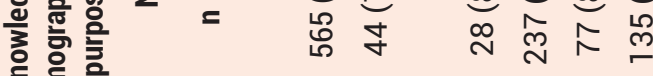
을

害

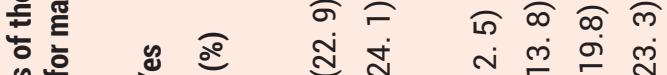

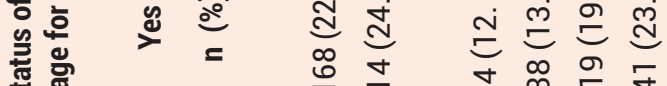

is

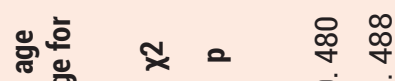

垔

金最

के

荡言 웡

跤.

跣

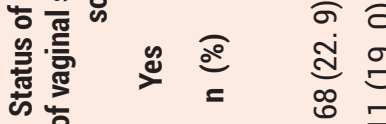

$=0$ 0 0 क

号

ले

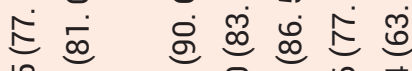

总宁

ని

$\begin{array}{ll}\sigma & 0 \\ \dot{\mathbb{d}} & 0 \\ 0 & 0 \\ 0 & =\end{array}$

它密

กล

के

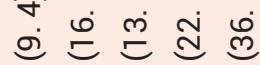

m of

$\circ \overline{8}$

ঙํ

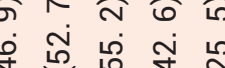

$\sum \stackrel{m}{\stackrel{m}{0}}$

$\underset{1}{0}$

อง

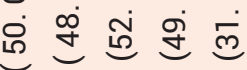

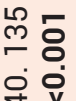

วิำ $=$

ம.

a \begin{tabular}{l}
2 \\
\hline
\end{tabular}

ิิ ติส

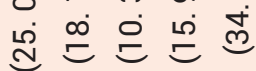

m $\mathrm{m}^{\circ} \circ \overline{\mathrm{c}}$

过安

ปั่

$\checkmark$ ¿

ธิศ $\widehat{\circ} \curvearrowleft$

m。

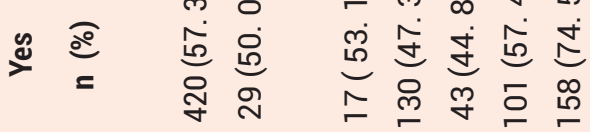

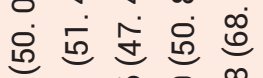

б न क्ष 西 क्ड 힝
గ్రె న్ స్ గ్రి

เก $ซ$

ก $อ$

ஸ்

음

亦

क 0

F 子

象宫

只

츠

$\stackrel{0}{\circ}$

遂 官

워

두

ल $\bar{\infty}$

递过孚

m 舟过 啇 N

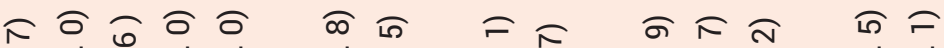

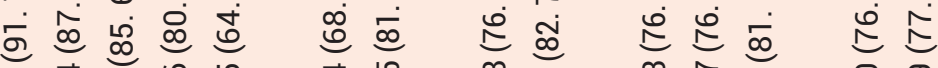

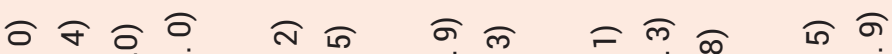

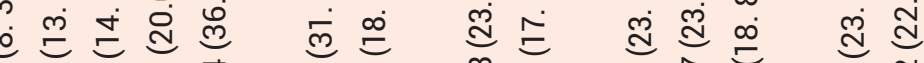

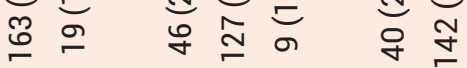

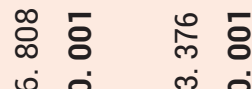

\&̊ㅠㅛ

กั ฮั ญ i v $\stackrel{m}{\circ}$

No

$\circ 0$

○

กิ ล

เ

능

ชิ

ल्ల

ח

电 $\overline{1}$

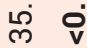

๙

¿

응ㅇ

동

$\infty 0^{\circ}$ $\infty$

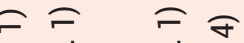

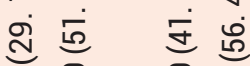

๙

ค่ ส

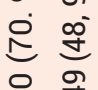

คี $อ$

舫 ঙं

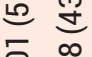

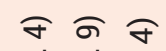

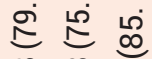

吕 $\frac{m}{\square}$
ชิ สิ $\stackrel{\infty}{N} \infty_{\infty}^{\infty}$ 占 $\widehat{0} \widehat{0} \widehat{\mathrm{f}} \widehat{=}$

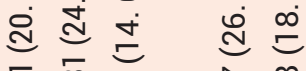

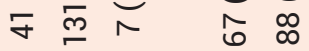

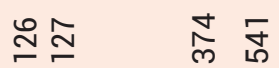
मं $0^{\circ} 0^{\circ}$

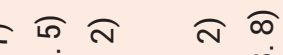

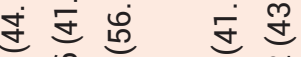

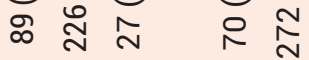
เ $\infty$ ล

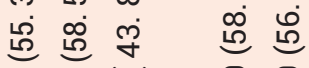
으 $\frac{\infty}{\sim}$ 으

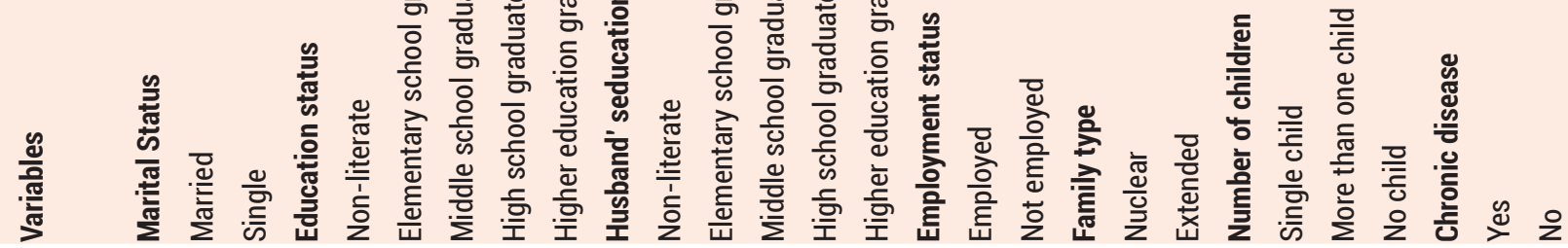


Table 5. Risk factors related to the practice of family planning and vaginal smear tests in women

\begin{tabular}{|c|c|c|c|}
\hline \multirow[t]{2}{*}{ Variables } & Risk factor & OR (\%95 Cl)* & p-Value ** \\
\hline & Marital status (Married, single) & $6.4(2.31-16.77)$ & $<0.001$ \\
\hline \multirow{2}{*}{$\begin{array}{l}\text { Using any modern family planning } \\
\text { method }\end{array}$} & Number of children in the family (One or more) & $2.1(1.47-3.21)$ & $<0.001$ \\
\hline & $\begin{array}{c}\text { Educational status of the mother (High school and } \\
\text { higher education) }\end{array}$ & $1.8(1.19-2.86)$ & 0.005 \\
\hline Experience in vaginal smear & Chronic disease (Yes-No) & $1.7(1.20-2.58)$ & 0.004 \\
\hline \multirow{2}{*}{ Experience in mammography } & Chronic disease (Yes-No) & $3.2(2.07-4.92)$ & $<0.001$ \\
\hline & Number of children in the family (One or more) & $1.7(1.02-2.87)$ & 0.04 \\
\hline
\end{tabular}

Of the participants, $70.7 \%$ answered the question about what could be the ideal delivery method if there were no risk for the mother or baby. The distribution of participants' answer regarding the preferred mode of delivery was as follows: vaginal birth (54.9\%), cesarean delivery (24.9\%), and no preference $(20.2 \%)$. Of those who stated that they would prefer normal delivery in case of a potential pregnancy, $75.2 \%$ believed it to be healthy, natural, and the best method while the others listed previous normal delivery experience, easiness, and being more conscious as reasons. Of the participants who would prefer cesarean, $48.6 \%$ had experienced normal delivery before, $36.6 \%$ believed it to be easy, painless, and healthy, and the others would prefer it because they were afraid of normal delivery or had advanced maternal age/diseases/tubal ligation.

\section{DISCUSSION}

The rate of participants who know the name of at least one family planning method in our study is $58.5 \%$. Known methods are OCP, IUD and condom respectively. The knowledge of modern family planning methods, such as injectable contraceptives, tube ligation, vasectomy, and implants, is low. In a study by Oztas et al. (2015) (11), similar to our study, the most known family planning methods are OCP $(70.8 \%)$, IUD (68.6\%), and condoms $(64.8 \%)$. In our study, less than half of the participants use a family planning method. Among the method users, the most popular methods are listed as condom, IUD, $\mathrm{OCP}$, traditional methods, tubal ligation, and injectable contraceptives, in this order. Similar to our study, ОCP and condoms are found to be the most commonly used method in all countries in the study of Johnson et al. (2013) (12) with about 500 women from each of the UK, Germany, Spain, Italy, and the United States. In our study, those who stated that they had information about the methods of family planning indicated that they received this information most from PCCs-MCHFP centers, which is followed by hospitals. There are other participants who stated that they were informed by friends, neighbors, television, and the internet. Similarly, in obtaining information, Sagiroglu and his colleagues
(2017) reported health institutions as the most popular information resource (13). These results highlight the importance of healthcare institutions and professionals in Turkey regarding the knowledge and practice of modern family planning methods in society. In studies conducted in Northern Ethiopia and Brazil $(14,15)$, it is stated that the information on the subject is received from the media the most. However, it is necessary to obtain information from health professionals, who should be the preferred information resource about the subject, which is pleasingly the most common information resource in our study. Free OCP and IUD applications and free condoms distributed in the PCCs in Turkey are important reasons for this outcome. In a study of Sunita et al. (2013), it is reported that one of the most important elements to reduce the gap between knowledge, attitude, and practice about contraception was that contraceptives could be regularly found in the healthcare centers and the quality of family planning services should be high (16).

About one-third of the participants already had vaginal smear before in our study. Among the reasons for vaginal smear tests, the most common reason was "when they were at hospital for control purposes", which was followed by "during a doctor visit with some complaints". In the study of Pehlivanoğlu et al. (2019) (17), the rate of having a vaginal smear is found to be $38.6 \%$ and in the study of Şen and Başar (2019) (18), it is $36 \%$. These rates are similar to those in our study. Approximately one in three women get smears. In the study of Şen and Başar (2019) (18), the doctor's recommendation, screening and infection findings are listed as the reasons for having a vaginal smear. The reasons for women to have vaginal smears are thought to be similar.

Participants ranked the people who have the greatest influence in determining the delivery method as doctors, followed by self, friends/relatives/acquaintances, husbands, and mothers. It is a fact known that doctors have a very important role when women decide the delivery method (19).

In our study, it is found that $27.4 \%$ of the participants 
gave birth by caesarean section. The cesarean section rate for the US in 2015 is $32 \%$, for the UK in 2016 it is $29.9 \%$, for Iran from $2008-2010$ it is $45.6 \%$ and for Italy it is $35 \%$ in $2014(20)$. It is $48 \%$ in 2013 THDS and $52 \%$ in 2018 THDS $(7,8)$. Rates are seen to be high both in Turkey and in some other countries.

While the reason for choosing normal delivery is because it is natural and healthy in both our study and other some studies; the most common reason for selecting cesarean is psychosocial such as easiness and painlessness of cesarean, the fear of normal delivery pain, the fear of giving birth, difficulty in a previous deliver, and in addition another reason for cesarean section is expressed as previous cesarean sections (21-26). In our study, onefourth of the participants stated that they would prefer cesarean section at their subsequent births. Since the previous cesarean section potentially affects this decision, proper evaluation of the cesarean section indications and giving adequate and correct counseling to the mother in the case of extreme fear and anxiety are important. At this stage, healthcare workers have some responsibilities. Most of the participants in our study stated that the ideal delivery method should be vaginal if there is no risk for the mother or the baby. Likewise, in the study of Yanikkerem et al. (2013) (27), 68.6\% of the participants stated that a woman with a chance of normal birth should not prefer cesarean delivery voluntarily. This may support the belief that in recent years the awareness of women of reproductive age has increased.

Based on the findings of the present study, there is a lack of information on $\mathrm{SRH}$ issues such as family planning, common cancers, and cancer screenings in women. Furthermore, even if these subjects are known by individuals, there are problems regarding their practices. In addition, although most participants considered vaginal birth as the ideal delivery method, the current cesarean delivery rate is not low. In this context, awareness raising studies and periodic training on the subject may be useful to women. However, it is crucial to keep the quality high and calibrate the content of these trainings according to the target group and to inform the target groups considering their own environment. In addition, the identification of missing or inaccurate information about the topic in women may be valuable in directing health policies.

\section{Limitations of the Study}

The study is limited to women who visited PCC in X city center. Privacy concerns of the women may have affected their responses. Incomplete/no answers to some questions of the questionnaire may be considered as a limitation.

Conflict of Interest: The authors declare that they have no competing interest

Financial disclosures: All authors report no financial interests or potential conflicts of interest.
Ethics committee approval : Before the study, the health directorate was informed and verbal permission was obtained. Then, approval was obtained from the Necmettin Erbakan University Meram Medical Faculty ethics committee (Number: 2014/88).

\section{REFERENCES}

1. World Health Organization (WHO), Reproductive health, 2020. Available at http://www.who.int/topics/reproductive_ health/en/

2. T.C. Sağlık Bakanlığı Ana Çocuk Sağlığı ve Aile Planlaması Genel Müdürlüğü. Üreme Sağlığına Giriş Katılımcı Kitabı. Ankara; 2009.

3. T.C. Sağlık Bakanlığı Ana Çocuk Sağlığı ve Aile Planlaması Genel Müdürlüğü. Güvenli Annelik Katılımcı Kitabı. Ankara; 2009.

4. Mylones I, Friese K. Indications for and risks of elective caesarean section. Dtsch Arztebl Int. 2015;112(29-30):48995.

5. Das V, Kumar N, Kumari V, Agarwal A, Pandey A, Agrawal S. Increasing rates of cesarean section, an upcoming public health problem: an audit of cesarean section in a tertiary care center of North India based on Robson classification. International Journal of Reproduction, Contraception, Obstetrics and Gynecology. 2017;6(11):4998-5002.

6. Hacettepe Üniversitesi Nüfus Etütleri Enstitüsü. Türkiye Nüfus ve Sağlık Araştırması, 2003. Hacettepe Üniversitesi Nüfus Etütleri Enstitüsü, Sağlık Bakanlığı Ana Çocuk Sağlığı ve Aile Planlaması Genel Müdürlüğü, Devlet Planlama Teşkilatı ve Avrupa Birliği, Ankara: Türkiye; 2004.

7. Hacettepe Üniversitesi Nüfus Etütleri Enstitüsü. Türkiye Nüfus ve Sağlık Araştırması, 2013. Hacettepe Üniversitesi Nüfus Etütleri Enstitüsü, T.C. Kalkınma Bakanlığı ve TÜBiTAK, Ankara: Türkiye; 2014.

8. Hacettepe Üniversitesi Nüfus Etütleri Enstitüsü. Türkiye Nüfus ve Sağlık Araştırması, 2018. Hacettepe Üniversitesi Nüfus Etütleri Enstitüsü, T.C. Kalkınma Bakanlığı ve TÜBITAK, Ankara: Türkiye; 2019.

9. Özkan S, Sakal FN, Avcı E, Civil EF, Tunca MZ. Kadınların doğum yöntemi tercihi ve ilişkili faktörler. Turk J Public Health. 2013;11(2):59-71.

10. Faul F, Erdfelder E, Lang AG, Buchner A. G*Power 3: A flexible statistical power analysis program for thesocial, behavioral, andbiomedicalsciences. Behavior Research Methods. 2007;39:175-91.

11. Öztaş Ö, Baydar Artantaş A, Kayhan Tetik B, Yalçıntaş A, Üstü Y, Uğurlu M. 18-49 yaş grubu evli kadınların üreme sağlığı ve kontrasepsiyon hakkındaki bilgi, tutum ve davranışları. Ankara Medical Journal. 2015;15(2):67-76.

12. Johnson S, Pion C, Jennings V. Current methods and attitudes of women towards contraception in Europe and America. Reproduc $\neg$ tive Health. 2013;10(7):1-9.

13. Sağıroğlu Çeliker P, Karataş Eray I, Yurdakul FE, Yavuz AF. Assessment of contraceptive method preferences and pregnancy rates during method usage of women. Ankara Medical Journal. 2017;17(1):21-8.

14. Melaku YA, Berhane Y, Kinsman J, Reda HL. Sexual and 
reproductive health communication and awareness of contraceptive methods among secondary school female students, northern Ethiopia: A cross-sectional study. BMC Public Health. 2014;14:252.

15. Oni TE, Prinsloo EAM, Nortje JD, Joubert G. High school students' attitudes, practices and knowledge of contraception in Jozini, KwaZulu-Natal. South African Family Practice. 2005;47(6):54-7.

16. Sunita TH, Desai RM. Knowledge, attitude and practice of contraception among women attending a tertiary care hospital in India. Int $\mathrm{J}$ Reprod Contracept Obstet Gynecol. 2013;2(2):172-6.

17. Pehlivanoğlu EFÖ, Sarı HB, Balcıoğlu H, Ünlüoğlu İ. Aile hekimliği polikliniğine başvuran kadın hastaların Human Papilloma Virüs aşılaması ve serviks kanseri hakkında bilgi,tutum ve davranışlarının değerlendirilmesi. Ortadogu Medical Journal. 2019;11(4):456-60.

18. Şen S, Başar FK. Kütahya bölgesinde yaşayan kadınların pap smear testi konusundaki farkındalıkları. STED. 2019; 28(1): 28-36.

19. Turnbull D, Wilkinson C, Yaser A, Carty V, Svigos J, Robinson $\mathrm{J}$. Women's role and satisfaction in the decision to have a caesarean section. Med J Aust. 1999;170:580-3.

20. WHO, Global Health Observatory Data Repository Maternal and Reproductive Health Births by Ceserian Section. Available at https://apps.who.int/gho/data/node.main. BIRTHSBYCAESAREAN?lang=en

21. Lee SI, Khang YH, Lee MS. Women's attitudes toward mode of delivery in South Korea a society with high cesarean section rates. Birth. 2004;31(2):108-16.

22. Duran ET, Atan ŞÜ. Kadınların sezaryen/vajinal doğuma ilişkin bakış açılarının kalitatif analizi. Genel Tıp Dergisi. 2011;21(3):83-8.

23. Stjernholm YV, Petersson K, Eneroth E. Changed indications for cesarean sections. Acta Obstet Gynecol Scand. 2010;89(1):49-53.

24. Fenwick J, Staff L, Gamble J, Creedy DK, Bayes S. Why do women request caesarean section in a normal, healthy first pregnancy? Midwifery. 2010;26(4):394-400.

25. Hopkins K. Are Brazilian women really choosing to deli-very by cesarean? Soc Sci Med. 2000;51(5):725-40.

26. Boyle A, Reddy UM. Epidemiology of cesarean delivery: The scope of the problem. Semin Perinatol. 2012; 36: 308-14.

27. Yanıkkerem E, Göker A, Piro N. Sezaryen doğum yapan kadınların doğum yöntemleri hakkında düşünceleri ve aldıkları bakım memnuniyeti. Selçuk Tıp Derg. 2013;29(2):7581. 